\title{
Sosialisasi dan Workshop Robotika untuk Skala Pelajar
}

\author{
Ida Rachmaniar Sahali ${ }^{1 *}$, Muh. Anshar ${ }^{1}$, Dewiani ${ }^{1}$, A. Ejah Umraeni Salam ${ }^{1}$, Intan Sari Areni ${ }^{1}$, \\ Azran Budi Arief ${ }^{1}$, Andani Achmad ${ }^{1}$, Hasniaty ${ }^{1}$, Ardiaty Arief ${ }^{1}$, Rhiza S. Sadjad ${ }^{1}$, \\ Merna Baharuddin ${ }^{1}$, Muh. Bachtiar Nappu ${ }^{1}$, \\ Departemen Teknik Elektro, Fakultas Teknik Universitas Hasanuddin ${ }^{1}$ \\ idar@unhas.ac.id*
}

\begin{abstract}
Abstrak
Bidang Robotika adalah hal yang menarik bagi pelajar. Ini terlihat dari antusiasme siswa SMP IT Ikhtiar yang ingin mengikuti kegiatan sosialisasi dan workshop Robotik yang diadakan oleh Departemen Teknik Elektro UNHAS. Kegiatan ini memberikan pengetahuan tentang dasar-dasar dan aplikasi terkini bidang Robotika serta mengajarkan siswa untuk dapat merakit robot sederhana dengan menggunakan bahan dan komponen elektronika yang mudah diperoleh. Workshop diadakan secara semi daring di mana terdapat 6 (enam) orang terdiri dari perwakilan guru dan siswa yang menghadiri kegiatan di Laboratorium dan terdapat pula lebih dari 50 orang siswa yang hadir secara virtual melalui teleconference. Untuk dapat memberikan pemahaman mengenai robotik bagi siswa, dibutuhkan pengajar yang mumpuni yang menguasai bidang elektro terkhusus robotika. Dari perbandingan hasil tes sebelum dan sesudah mengikuti kegiatan oleh siswa diperoleh peningkatan pengetahuan yang signifikan. Selain itu, siswa juga berhasil merakit robot dengan menggunakan bahan dan komponen yang telah disediakan Sebagai bahan keberlanjutan program, robot yang dirakit oleh siswa kemudian diberikan kepada mereka untuk dapat dipelajari kembali.
\end{abstract}

Kata Kunci: Workshop; Robotik; Sensor; SMP IT Ikhtiar: Ekstrakurikuler.

\begin{abstract}
The field of robotics is a great interest to students. This can be seen from the enthusiasm of SMP IT Ikhtiar students who want to take part in socialization and workshops of robotic held by the Electrical Engineering Department of UNHAS. This activity provides knowledge about the basics and current applications of the field of Robotics and teaches students to be able to assemble simple robots using easily obtained electronic materials and components. The workshop was held semi-online where there were 6 (six) people consisting of teacher and student representatives who attended activities in the laboratory and there were also more than 50 students who attended virtually via teleconference. To be able to provide an understanding of robotics for students, it requires qualified teacher who master the field of electrical engineering, especially robotics. From the comparison of the pre-test and post-test results before and after participating in the activity, it was obtained a significant increase in the knowledge of the students. In addition, students also succeeded in assembling robots using the materials and components that had been provided. As materials for the sustainability of the program, the robots assembled by students were then given to them to be studied again.
\end{abstract}

Keywords: Workshop; Robotics; Sensor; SMP IT Ikhtiar, Ekstrakurikuler.

\section{Pendahuluan}

Di era globalisasi, setiap pelajar diharapkan memiliki wawasan yang luas, kemampuan berfikir dan berkreasi yang baik agar dapat beradaptasi dengan perkembangan Teknologi dan Informasi (IT) yang sangat cepat. Oleh karena itu, setiap jenjang sekolah menitikberatkan pendidikan tidak hanya pada pengembangan kemampuan berfikir ilmiah dan teoritis tetapi proses berfikir dan tingkah laku seseorang juga perlu dikembangkan. Salah satu sarana untuk pendidikan tingkah laku melalui kegiatan ekstrakurikuler. Kegiatan ekstrakurikuler adalah kegiatan yang dilakukan oleh pelajar atau mahasiswa di luar jam belajar kurikulum standar (utama). Pada kegiatan 
ekstrakurikuler, pelajar dapat memilih sendiri kegiatan sesuai dengan bakat dan minatnya (Saputra, 2015).

Kegiatan ekstrakurikuler yang cukup popular di sekolah adalah robotika. Beberapa manfaat mempelajari robotika bagi pelajar adalah : (1) Merangsang siswa untuk berfikir sistematis untuk menyelesaikan suatu masalah, (2) Meningkatkan kemampuan motorik halus siswa, (3) Meningkatkan kemampuan berimajinasi dan berkreasi ketika mendesain sebuah robot, (4) Melatih kerjasama dalam tim, meningkatkan kepercayaan diri, menerima dan menghargai pendapat orang, serta berani tampil untuk menyampaikan ide dan gagasan kreatifnya. (5) Melatih kesabaran dan ketekunan dalam membangun sebuah proyek.

Bidang Teknik Elektro dan Robotika adalah bidang yang sangat menarik bagi pelajar, termasuk siswa(i) di SMP IT Ikhtiar. Beberapa sekolah mulai melirik untuk menjadikan Robotika menjadi kegiatan ekstrakurikuler di sekolahnya. Hanya saja dibutuhkan tenaga ahli yang mumpuni untuk bisa mengajarkan bidang tersebut. Untuk mengatasi hal tersebut, pihak sekolah dapat bekerja sama dengan pihak eksternal untuk memberikan pembelajaran tersebut.

SMPT IT Ikhtiar atau sekolah mitra merupakan sekolah unggulan yang menerapkan nilai-nilai Qur'ani dengan sistem pembelajaran modern, berakhlak mulia, berdisiplin tinggi, berwawasan luas, dan berkarakter dengan ciri khas Full Day School. SIT Ikhtiar adalah sekolah unggulan dengan Integrated Curriculum (mengitegrasikan nilai-nilai islami dalam setiap mata pelajaran), every day with Qur'an (setiap hari bersama Qur'an), Student Active Learning, komunikatif interventif, leadership dan membership serta entrepreneurship. Adapun Visi dari SMP IT Ikhtiar adalah Terwujudnya Generasi Berkarakter, Cerdas, Kompetitif, dan Cinta Lingkungan. Sedangkan Misi dari SMP IT Ikhtiar adalah Memiliki Akhlakul Karimah dan Cinta Lingkungan Cerdas Akademik dan Non Akademik Unggul dalam Prestasi (SMP IT Ikhtiar, 2015).

SMP IT Ikhtiar berlokasi di Jl. Sunu Kompleks Unhas Baraya, Kecamatan Tallo Kotamadya Makassar. Sekolah ini berjarak sekitar $\pm 20 \mathrm{Km}$ dari Fakultas Teknik Unhas. Peta Lokasi SMP IT Ikhtiar diberikan pada gambar 1.
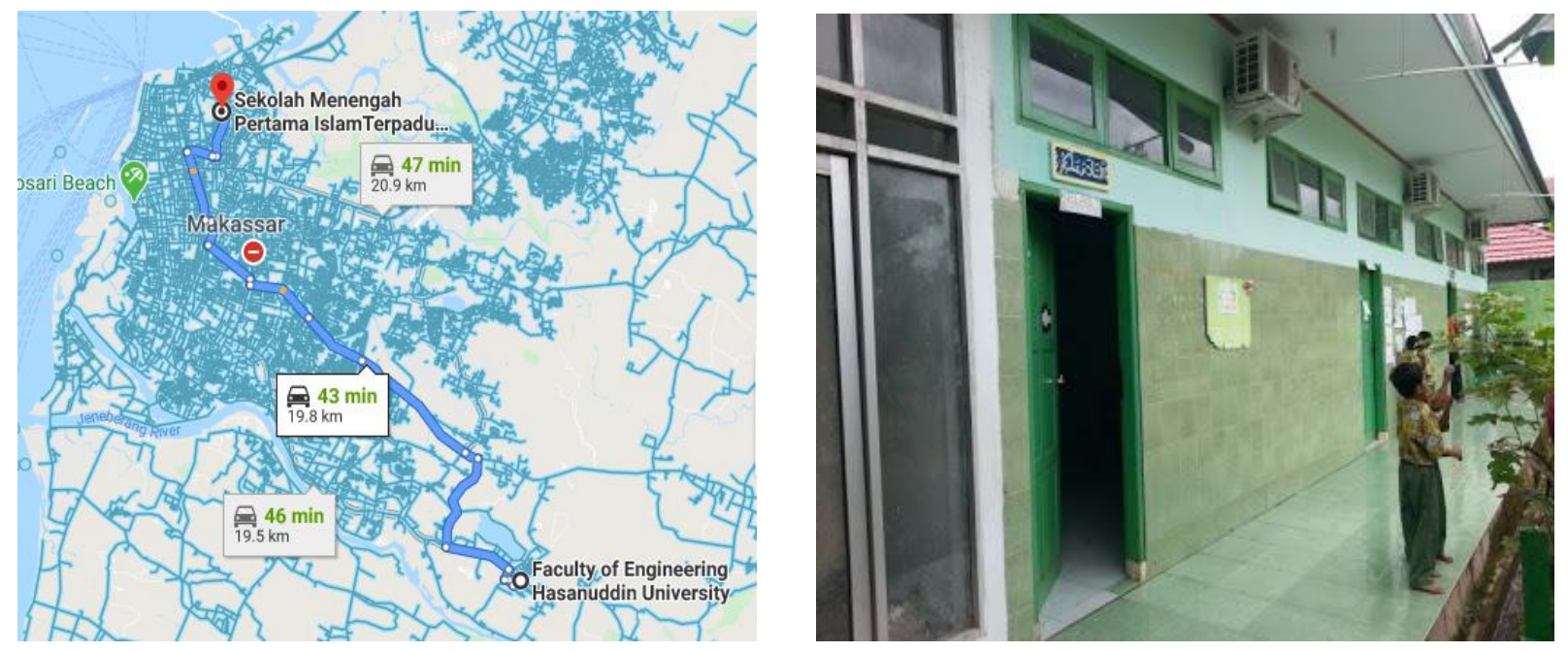

Gambar 1. Peta lokasi serta tampilan sekolah mitra

Kegiatan pengabdian yang melibatkan mahasiswa dan tim pelaksana ini bertujuan untuk memberikan pemahaman dasar mengenai robotika dan teknologinya serta merakit robot 
sederhana dengan menggunakan bahan yang mudah diperoleh bagi pelajar tingkat Sekolah Menengah Pertama. Sosialisasi serta workshop ini diharapkan akan membuka wawasan dan pengetahuan siswa serta cikal bakal lahirnya kegiatan ekstrakurikuler Robotika di sekolah mitra.

\section{Latar Belakang}

Istilah robot berasal dari kata robota dalam Bahasa Cekoslowakia yang berarti pekerja atau kuli yang tidak pernah lelah. Secara sederhana robot adalah perangkat elektro-mekanis yang dapat bereaksi terhadap lingkungannya dan mengambil keputusan secara otonom atau aksi guna mencapai unjuk kerja tertentu (Anshar 2020). Sedangkan berdasarkan Robot Institute of America (1979), robot adalah sesuatu yang dapat diprogram dan diprogram ulang, memiliki manipulator mekanik (penggerak), didesain untuk memindahkan barang-barang, memiliki berbagai program yang fleksibel dan disesuaikan untuk melaksanakan berbagai macam tugas (Anshar 2020).

Teknologi Robotika sangat penting artinya bagi kehidupan manusia. Beberapa fungsi robot diantaranya adalah (Teavuihuang, 2020):

1. Bidang industri

Robot digunakan pada berbagai proses utamanya pada proses produksi. Robot membuat produktivitas industri menjadi lebih tinggi, efisien serta mengurangi risiko terjadinya kesalahan manusia (human error).

2. Digunakan pada medan yang berisiko

Robot digunakan sebagai pengganti manusia untuk tugas yang berbahaya dan berisiko, masuk ke daerah yang berbahaya ataupun melakukan sesuatu yang berbahaya bagi kelangsungan hidup manusia. Contoh : Untuk mendeteksi limbah nuklir, Robot pemadam api.

3. Untuk hiburan

Robot juga bisa diciptakan untuk menyajikan hiburan bagi manusia. Contoh : Dancing Robot (Robot yang bisa menari), Robot yang dapat bernyanyi, Robot untuk kontes atau perlombaan (Soccer Robot). Terdapat kompetisi tahunan bagi Robot untuk dipertandingkan.

4. Bagian pelayanan

Robot dapat juga dibuat dan diprogram untuk memberikan pelayanan sehingga dapat menggantikan fungsi manusia dan lebih efisien. Contoh : pada rumah sakit, robot dapat diatur untuk melayani pasien, mengantarkan makanan ke kamar pasien dan bahkan untuk melakukan pemeriksaan dasar. Di masa pandemik, di mana interaksi tenaga kesehatan dengan pasien ingin dikurangi maka keberadaan robot sangat penting yang dapat diprogram untuk menangani pasien menjalankan fungsi-fungsi dasar tenaga kesehatan.

5. Asisten Rumah Tangga

Robot dapat pula diprogram untuk membantu tugas rumah tangga dalam hal menjaga kebersihan serta menjaga keamanan. Di saat teknologi IoT (Internet Of Things) semakin berkembang kemampuan dari Robot juga semakin tinggi.

Terdapat berbagai macam robot, diantaranya (1) robot yang dapat bergerak (Mobile Robot) dan robot yang tidak dapat bergerak/diam di tempat (Non - Mobile Robot), (2) Robot berkaki dan Robot Beroda, (3) Robot untuk kebutuhan kompetisi dan hiburan seperti : Robot Soccer, Robot Pemadam Api, Robot Search and Rescue, Dancing Robot.

Sebuah robot sederhana minimal memiliki 3 (tiga) unsur yaitu : otak robot, penggerak dan sensor. Otak robot biasanya merupakan mikrokontroler, sensor berfungsi untuk mengindera keadaan lingkungan serta penggerak untuk menjalankan robot. Mikrokontroler yang popular 
digunakan adalah Arduino, karena bersifat open source, telah banyak tersedia library yang mendukung implementasi program.

\section{Metode}

Sehubungan dengan permasalahan yang telah disebutkan di atas, maka kegiatan pengabdian ini menawarkan kegiatan sosialisasi dan workshop teknologi Robotika untuk skala pelajar dengan pemateri dari Tim Pelaksana. Di tengah pandemik virus corona maka kegiatan dilakukan secara semi daring. Perwakilan guru serta siswa hadir di Laboratorium Antena Departemen Elektro Fakultas Teknik Unhas untuk mengikuti kegiatan workshop dengan tetap memperhatikan protokol kesehatan dan sebagian yang lain mengikuti kegiatan secara virtual melalui aplikasi teleconference.

\subsection{Target Capaian}

Kegiatan ini menargetkan capaian peningkatan wawasan, ilmu pengetahuan siswa serta guru mengenai teknologi robotika yang sedang berkembang saat ini serta bertambahnya keterampilan siswa dalam merakit robot sederhana.

\subsection{Implementasi Kegiatan}

Pelaksanaan kegiatan terdiri dari penyiapan modul kit pembelajaran serta koordinasi dengan sekolah mitra. Dari koordinasi yang dilakukan kemudian ditentukan jadwal pelaksanaan kegiatan. Tim pelaksana kemudian merancang materi yang dapat diberikan untuk skala pelajar yang kira-kira dapat diterima dan diselesaikan oleh pelajar.
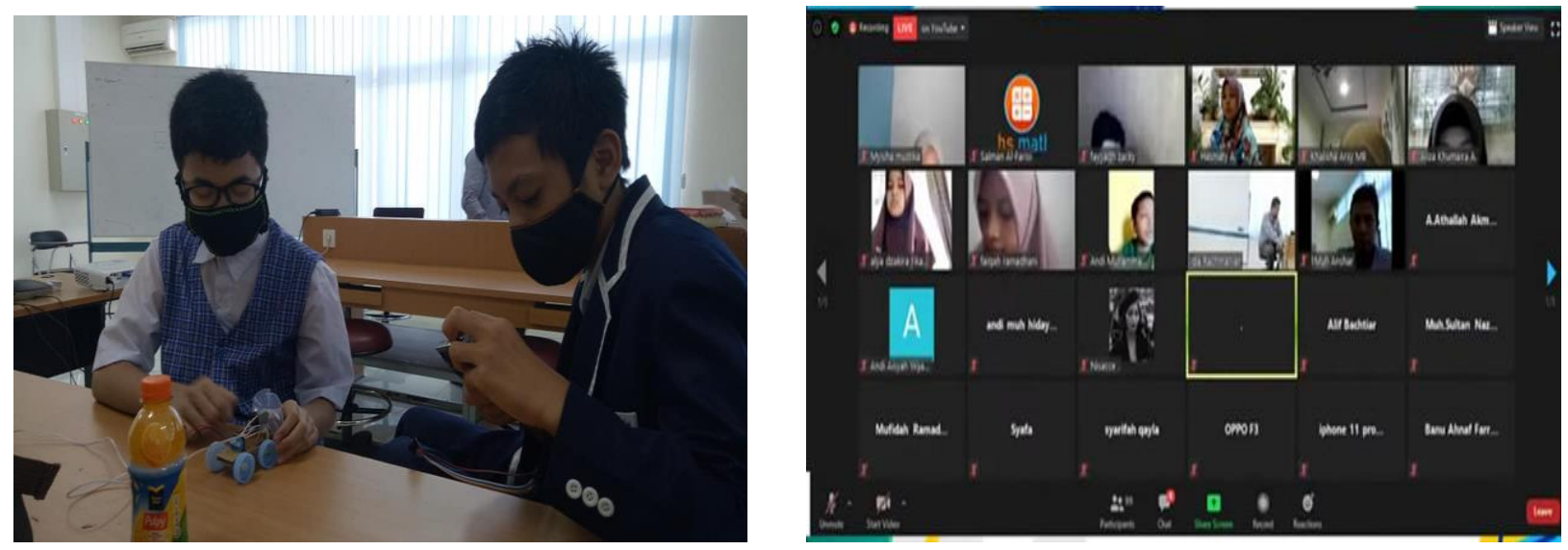

Gambar 2. Aktivitas siswa yang mengikuti kegiatan secara semi daring

\section{Hasil dan Diskusi}

Kegiatan pengabdian masyarakat diikuti oleh 6(enam) peserta secara luring dan lebih dari 50 peserta secara daring yang mengikuti kegiatan sampai akhir acara. Peserta luring kemudian dibagi menjadi tiga kelompok di mana masing-masing kelompok diberikan komponen dan bahan untuk merakit robot sederhana dibantu oleh tim tutor dari mahasiswa. Sosialisasi dimulai dengan pemberian materi pendahuluan mengenai robotika, teknologi serta aplikasinya yang sangat berkembang saat ini. Sebelumnya diadakan tes terlebih dahulu untuk mengetahui pemahaman awal peserta mengenai robot. 
Setelah mengikuti materi, dilanjutkan dengan hands-on merakit robot dengan menggunakan bahan, komponen dan alat yang telah diberikan. Selama proses kegiatan, peserta terlihat antusias untuk terlibat dalam kegiatan.

Di akhir sesi siswa diberi post-test dengan soal yang sama yang diberikan saat pre-test. Persentase hasil tes siswa yang mengikuti kegiatan secara luring (luar jaringan) diberikan pada gambar dibawah.

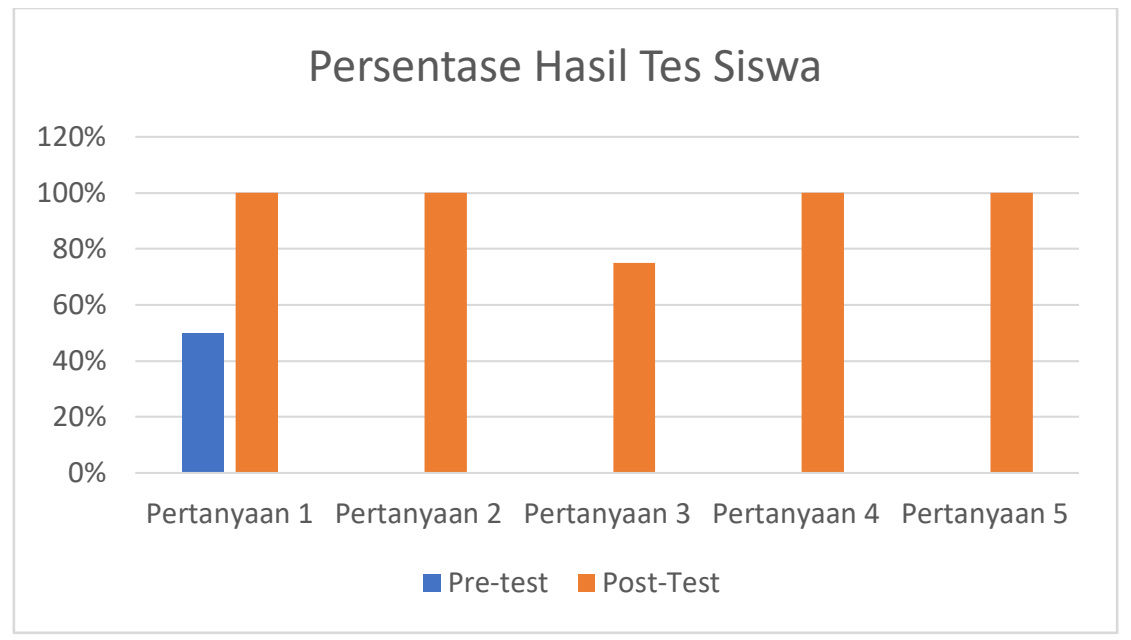

Gambar 3. Persentase hasil test siswa sebelum dan sesudah pemberian materi

Dari gambar tersebut diketahui pengetahuan dan pemahaman siswa sebelum mengikuti kegiatan masih kurang. Setelah mengikuti workshop pengetahuan siswa bertambah. Secara keseluruhan, siswa dapat menyerap materi yang diberikan selama workshop.

\section{Kesimpulan}

Tingkat pengetahuan dan pemahaman siswa semakin meningkat melalui antusiasme yang terbangun selama mengikuti kegiatan. Dari hasil post-test terlihat adanya peningkatan pengetahuan yang signifikan dari peserta kegiatan. Diharapkan ke depannya semakin bertambah siswa yang ingin belajar dan menguasai Robotik dan nantinya dapat terbentuk kegiatan ekstrakurikuler Robotika di SMP IT Ikhtiar.

\section{Ucapan Terima Kasih}

Ucapan terima kasih kepada Kepala Sekolah SMP IT Ikhtiar beserta jajarannya terkhusus guru pembimbing beserta siswa yang telah bersedia hadir pada kegiatan sosialisasi dan workshop robotika ini. Ucapan terima kasih kepada seluruh tim pelaksana yang telah membantu bagi terlaksananya kegiatan. Ucapan terima kasih kepada Fakultas Teknik Unhas melalui hibah Pengabdian LBE yang telah mampu mendukung terlaksananya kegiatan ini. Ucapan terima kasih kepada tim mentor yang tergabung dalam riset grup, Social, Cognitive Robotics and Advanced Artificial Intelligent Research Centre, Teknik Elektro UNHAS.

\section{Daftar Pustaka}


Anshar, Muh (2020). Implementasi Teknologi Robotika sebagai Inovasi untuk Berkarya. Materi Sosialisasi dan Workshop Robotika untuk Pelajar.

Saputra, Laurentius K. P dan Lukito, Yuan. (2015). Pelatihan Pengantar Robotika Berbasis Lego NXT Sebagai Kegiatan Ekstrakurikuler Siswa SMA. Seminar Nasional Pengabdian Kepada Masyarakat. Doi : http://lecturer.ukdw.ac.id/yuan/publikasi/2016-PELATIHANPENGANTAR-ROBOTIKA-SENDIMAS.pdf.

SMP IT Ikhtiar. (2015). Profil Singkat. Terdapat pada laman http://www.sitikhtiar.com/profilsingkat/. Diakses pada tanggal 17 Maret 2020.

Teavuihuang. (2020). Fungsi Robot dalam Kehidupan Manusia, terdapat pada laman https://teavuihuang.com/fungsi-robot-dalam-kehidupan-manusia.php, diakses pada tanggal 12 Oktober 2020. 